\title{
Pengaruh Implementasi Standar Akuntansi Pemerintahan dan Sistem Informasi Akuntansi Terhadap Kualitas Laporan Keuangan
}

\author{
Rukmi Juwita \\ Politeknik Pos Indonesia \\ J1. Terusan Sari Asih No. 54, Bandung \\ E-Mail: witawilanggana@rocketmail.com
}

\begin{abstract}
The purpose of this study to determine and analyze (1) influence the implementation of government accounting standards and implementation of accounting information system partially on the quality of financial reporting in areas of the city/county in the province of West Java (2) influence the implementation of government accounting standards and implementation of accounting information systems simultaneously on the quality of financial reporting in the area of the city/county in the province of west Java. The results showed that the Pearson correlation test results to variable implementation of government accounting standards and implementation of accounting information systems have a very strong relationship / linked to the quality of financial statements. Results of regresion testing simultaneously with the partial $F$ test and $t$-test, showed that the implementation of government accounting standards and implementation of accounting information system significantly affect the quality of financial statements.
\end{abstract}

Keywords: government accounting standard, accounting information system, quality of financial reporting.

\begin{abstract}
ABSTRAK
Penelitian ini bertujuan untuk mengetahui dan menganalisis (1) pengaruh implementasi standar akuntansi pemerintahan dan implementasi sistem informasi akuntansi secara parsial terhadap kualitas laporan keuangan di wilayah kota/kabupaten di provinsi Jawa barat (2) pengaruh implementasi standar akuntansi pemerintahan dan implementasi sistem informasi akuntansi secara simultan terhadap kualitas laporan keuangan di wilayah kota/kabupaten di Propinsi Jawa barat. Hasil penelitian menunjukan bahwa hasil pengujian korelasi pearson terhadap variable implementasi standar akuntansi pemerintahan dan implementasi sistem informasi akuntansi memiliki hubungan yang sangat kuat/erat dengan kualitas laporan keuangan. Hasil pengujian regresi secara simultan dengan uji $\mathrm{F}$ maupun parsial dengan uji t, memperlihatkan bahwa implementasi standar akuntansi pemerintahan dan implementasi sistem informasi akuntansi berpengaruh secara signifikan terhadap kualitas laporan keuangan.
\end{abstract}

Kata Kunci: standar akuntansi pemerintahan, sistem informasi akuntansi, kualitas laporan keuangan. 


\section{PENDAHULUAN}

Perkembangan akuntansi sektor publik, khususnya di Indonesia semakin pesat dengan adanya Era Reformasi dalam pelaksanaan kebijakan pemerintahan, Otonomi Daerah dan Desentralisasi Fiskal yang menitik beratkan pada PemerintahDaerah. Selain itu, maraknya globalisasi yang menuntut daya saing di setiap negara juga menuntut daya saing di setiap Pemerintah Daerah, dimana daya saing Pemerintah Daerah ini diharapkan akan mampu tercapai melalui peningkatan kemandirian pemerintahan. Dengan bergulirnya Undang-Undang Nomor 22 Tahun 1999 yang diperbaharui dengan UndangUndang No 32 tahun 2004 tentang Pemerintahan Daerah dan Undang-Undang Nomor 25 Tahun 1999 yang diperbaharui dengan Undang-Undang No. 33 tahun 2004 tentang Perimbangan Keuangan Pemerintah Pusat dan Daerah, merupakan payung hukum Pemerintah daerah yang antara lain adalah mengenai pola-pola aplikasi pertanggungjawaban keuangan daerah, yang sangat terkait dengan reformasi regulasi keuangan Negara,

Fenomena yang terjadi dalam perkembangan sektor publik di Indonesia sekarang ini adalah menguatnya tuntutan akuntabilitas atas lembaga -lembaga publik baik di pusat maupun di daerah, akuntabilitas dapat diartikan sebagai bentuk kewajiban mempertanggungjawabkan keberhasilan atau kegagalan pelaksanaan misi organisasi dalam mencapai tujuan dan sasaran yang telah ditetapkan sebelumnya melalui suatu media pertanggungJawaban yang dilaksanakan secara periodik (Stanbury, 2003), Fenomena tersebut menunjukkan bahwa tuntutan masyarakat terhadap pelaksanaan akuntabilitas publik oleh organisasi pemerintah, baik Pemerintah Pusat maupun Pemerintah Daerah semakin menguat, berkenaan dengan hal tersebut penciptaan akuntabilitas publik harus dilaksanakan dalam sistem dan standar akuntansi pemerintahan untuk dapat menciptakan Good Governance. Good Governance sering diartikan sebagai pemerintahan yang baik dengan menyelenggarakan manajemen pembangunan yang bertanggungJawab dan sejalan dengan prinsip demokrasi dan pasar yang efisien, penghindaran salah alokasi dana Investasi, pencegahan korupsi baik secara politik maupun administratif, dan menjalankan disiplin anggaran.
Undang-Undang No 17 tahun 2003, pasal 32 menegaskan bahwa Pemerintah Daerah di haruskan menyampaikan laporan keuangan sebagai bentuk pertanggungJawaban pelaksanaan Anggaran Pendapatan dan Belanja Daerah (disingkat APBD) kepada Dewan Perwakilan Rakyat Daerah (disingkat DPRD), Laporan Keuangan dimaksud setidaktidaknya meliputi Laporan Realisasi Anggaran, Neraca, Laporan Arus Kas, dan Catatan atas Laporan Keuangan, Penelitian tentang pentingnya laporan keuangan telah dilakukan oleh Winfield (1978), Chang and Mos (1985), Boyne and Law (1991) yang mengemukakan pentingnya laporan tahunan sebagai alat memperkuat akuntabilitas, Marston and Shrives (1991) menyimpulkan bahwa laporan keuangan merupakan dokumen yang paling komprehensif yang tersedia bagi publik dan sebagai alat pengungkap utama, Parker (1982) menekankan pentingnya laporan tahunan sebagai media komunikasi masa meskipun laporan tahunan bukanlah satu-satunya sumber informasi tentang kinerja organisasi, namun masih dipandang sebagai sumber penting karena luas cakupan dan ketersediaannya, informasi yang dikomunikasikan kepada stakeholder melalui laporan tahunan adalah fokus dari riset yang merupakan seperangkat alat dalam kerangka kerja akuntabilitas publik (Coy et al, 2002; Hooks et al, 2002).

Undang-UndangNo 17tahun2003 mengisyaratkan bahwa laporan pertanggungjawaban pemerintah atau laporan keuangan pemerintah pada gilirannya harus diaudit oleh Badan Pemeriksa Keuangan (di singkat BPK) sebelum disampaikan kepada pihak legislatif sesuai dengan kewenangannya. Pemeriksaan BPK di maksud adalah dalam rangka pemberian pendapat (Opini) sebagimana diamanatkan oleh UU No 15 tahun 2004 tentang pemeriksaan pengelolaan dan tanggung Jawab Keuangan Negara. Dalam rangka mengahasilkan laporan keuangan yang berkualitas laporan keuangan harus memenuhi kriteria yang memadai yaitu memiliki relevansi, dapat diandalkan, dapat dinilai atau dibandingkan, dan dapat dipahami, Keempat kriteria tersebut merupakan hal yang sangat penting bagi terciptanya kualitas laporan keuangan yang baik sebagai bukti pertanggungJawaban penggunaan anggaran dari pemerintah.

Dari hasil pemeriksaan BPK terhadap laporan keuangan pemerintah daerah yang berupa opini, BPK juga menerbitkan laporan hasil pemeriksaan 
atas Sistem Pengendalian Intern (disingkat SPI) pada setiap entitas yang diperiksa, dalam evaluasi tersebut BPK di antaranya menemukan 754 kasus kelemahan SPI karena kelemahan Sistem pengendalian akuntansi dan pelaporan. Penemuan kasus-kasus tersebut di atas mengindikasikan bahwa masih ada permasalahan dalam proses transformasi akuntasi sektor publik di Indonesia, harapan atas berfungsinya Akuntansi dalam rangka mengurangi Korupsi dan Kolusi, meningkatkan efisiensi dan efektitas serta mewujudkan transparansi dan akuntabilitas pengelolaan keuangan Negara ternyata masih belum dapat menunjukan kontribusinya secara maksimal.

Terkait dengan fenomena tersebut tentang Akuntabilitas dan Transparansi melalui Opini Laporan Keuangan Pemerintah Daerah, Jawa Barat sebagai Provinsi yang sedang melaksanakan pemantapan kinerja pemerintah daerahnya melalui peningkatan kualitas pengelolaan dan pertanggungjawaban keuangan daerah, Juga berkepentingan dengan opini BPK terhadap kualitas laporan keuangan daerahnya. Dalam IHPS semester I tahun 2010 dan IHPS semester 2 tahun 2010 yang di laporkan BPK, kabupaten dan kota se Provinsi Jawa barat sebagian besar belum mendapat Opini WTP, dapat di lihat dalam Tabel 1.

Tabel 1. menunjukan bahwa laporan keuangan yang dihasilkan oleh LKPD di wilayah Jawa Barat masih belum sesuai dengan yang di harapkan, dari 26 entitas LKPD yang telah diperiksa oleh BPK sebagian besar memperoleh opini WDP (wajar dengan pengecualian), BPK melaporkan hasil Evaluasi SPI terhadap Laporan Keuangan provinsi Jawa Barat, di temukan 76 kasus kelemahan Sistem pengendalian akuntansi dan pelaporan, artinya di lingkungan pemerintahan Jawa Barat masih ada permasalahan dalam proses transformasi akuntansi sektor publik, dalam hal fungsi akuntansinya. Hal ini mengindikasikan masih banyak ditemukan ketidakberesan, ketidakteraturan dan ketidakbenaran, dan bahkan penyimpangan dalam pengelolaan serta pertanggungJawaban keuangan daerah termasuk banyaknya aset negara yang dikelola secara tidak layak dan dilaporkan secara tidak wajar dalam laporan keuangan, pelaksanaan realisasi belanja dan pendapatan yang tidak akuntabel, yang pada ujungnya berimbas pada laporan keuangan yang tidak disajikan secara wajar sesuai dengan standar akuntansi pemerintahan. Selain Standar Akuntansi Pemerintah, penyusunan laporan keuangan juga harus sesuai dengan ketentuan peraturan perundanganundangan lainnya, seperti Peraturan Presiden dalam hal kegiatan pengadaan (Perpres 54 Tahun 2010), Peraturan Menteri Dalam Negeri dalam hal penganggaran (Permendagri 13 dan 59 serta 21), Peraturan Menteri Dalam Negeri terkait pengelolaan aset atau barang milik daerah (permendagri 17) dan ketentuan-ketentuan terkait dengan pengelolaan keuangan daerah lainnya.

Tabel 1. Opini LKPD Provinsi Jawa Barat Tahun 2009

\begin{tabular}{|c|c|c|c|}
\hline \multicolumn{2}{|r|}{$\begin{array}{c}\text { Entitas Pemerintah Daerah } \\
\text { Propinsi Jawa Barat }\end{array}$} & \multirow[t]{2}{*}{$\begin{array}{l}\text { Di laporkan } \\
\text { pada IHPS I }\end{array}$} & \multirow{2}{*}{$\begin{array}{c}\begin{array}{c}\text { Di laporkan } \\
\text { pada IHPS II }\end{array} \\
\text { WDP }\end{array}$} \\
\hline & Propinsi Jawa Barat & & \\
\hline 1 & Kab. Bandung & & WDP \\
\hline 2 & Kab. Bandung Barat & & TMP \\
\hline 3 & Kab. Bekasi & & WDP \\
\hline 4 & Kab. Bogor & WDP & \\
\hline 5 & Kab. Ciamis & & WDP \\
\hline 6 & Kab. Cianjur & & TMP \\
\hline 7 & Kab. Cirebon & WDP & \\
\hline 8 & Kab. Garut & & WDP \\
\hline 9 & Kab. Indramayu & & WDP \\
\hline 10 & Kab. Karawang & & WDP \\
\hline 11 & Kab. Kuningan & & WDP \\
\hline 12 & Kab. Majalengka & & WDP \\
\hline 13 & Kab. Purwakarta & WDP & \\
\hline 14 & Kab. Subang & & WDP \\
\hline 15 & Kab. Sukabumi & WDP & \\
\hline 16 & Kab. Sumedang & WDP & \\
\hline 17 & Kab. Tasikmalaya & & WDP \\
\hline 18 & Kota Bandung & & TMP \\
\hline 19 & Kota Banjar & WDP & \\
\hline 20 & Kota Bekasi & & TMP \\
\hline 21 & Kota Bogor & & WDP \\
\hline 22 & Kota Cimahi & & WDP \\
\hline 23 & Kota Cirebon & WDP & \\
\hline 24 & Kota Depok & & WDP \\
\hline 25 & Kota Sukabumi & WDP & \\
\hline 26 & Kota Tasikmalaya & & WDP \\
\hline
\end{tabular}

Sumber: BPK, IHPS semester II Tahun 2010 
Berikut ini beberapa hasil penelitan terdahulu yang mengkaji mengenai pengaruh penerapan Standar Akuntansi Pemerintahan terhadap kualitas laporan keuangan, penelitian yang dilakukan oleh Sri Jayani, Implementasi Standar Akuntansi Pemerintah di Badan Pengawasan Daerah Kabupaten Sleman" (Jogya: Fakultas EkoNomi UGM, 2006) merupakan penelitian ekspolarif dengan maksud mengidentifikasikan praktek akuntansi yang dilakukan oleh Badan Pengawas Daerah Kabupaten Sleman. Hasil penelitian ini menyatakan bahwa praktek di daerah Kabupaten Sleman telah mengacu pada tata cara praktek akuntansi yang telah ditetapkan oleh pemerintah yaitu Standar Akuntansi Pemerintah melalui Peraturan Pemerintah Nomor 24 tahun 2005, pemakaian standar akuntansi ini cenderung dilakukan karena dapat memperbaiki sitem yang sudah dipergunakan sebelumnya sehingga informasi keuangan sebagai bahan bagi pengguna laporan keuangan menjadi lebih akurat dan kesalahan dalam pengambilan keputusan bisa dihindarkan. Standar Akuntansi Pemerintahan merupakan persyaratan yang mempunyai kekuatan hukum dalam upaya peningkatan kualitas laporan keuangan pemerintah di Indonesia, Roesyanto (2007) menyatakan bahwa "rata-rata pemerintah daerah belum dapat menyusun laporan keuangan daerah sesuai dengan ketentuan yang ada yaitu Peraturan Pemerintah No.24 Tahun 2005 mengenai Standar Akuntasi Pemerintahan". Dalam Government Finance Review, kajian mengenai penerapan Standar Akuntansi Pemerintah juga dilakukan oleh Jeffrey L esser (1992) yang menganalasis mengenai "GASB's implementation of the new measurement focus and basis on accounting " hasil pelaporannya menunjukan bahwa perubahan dalam Standar Akuntansi Pemerintahan sebagai dasar pelaporan keuangan akan terakses pada penurunan kredibilitas laporan keuangan pemerintah dan kemampuannya untuk dipahami oleh para pengguna, khususnya bagi entitas pelaporan yang belum sepenuhnya dapat menerapkan Standar Akuntansi Pemerintah yang baru. Penelitian yang dilakukan oleh Wiwin Mulyani (2007) yang meneliti tentang pengaruh penerapan Standar Akuntansi pemerintahan terhadap kualitas laporan keuangan pemerintah daerah, Hasil penelitian menunjukan terdapat pengaruh positif yang signifikan terhadap Kualitas Laporan Keuangan.

Laporan keuangan pemerintah merupakan informasi yang sangat bermanfaat bagi penggunanya, untuk menghasilkan informasi yang berkualitas baik, sebuah organisasi harus mempunyai Sistem Informasi yang baik, sistem Informasi yang bertujuan menghasilkan informasi keuangan disebut dengan Sistem Informasi Akuntansi, hal ini berlaku baik untuk organisasi bisnis maupun organisasi sektor publik seperti di Pemerintah Daerah (Laudon \& Laudon, 2007). Sistem Informasi Akuntansi mengacu pada Peraturan Pemerintah No 56 tahun 2005 yang direvisi oleh Peraturan Pemerintah No 65 tahun 2010, aturan pelaksanaannya adalah Peraturan Menteri Dalam Negeri (Permendagri) No 13 tahun 2006 dan Peraturan Menteri Dalam Negeri No 59 Tahun 2007, Sistem ini berbasis pada jaringan komputer yang mampu menghubungkan dan mampu menangani konsolidasi data antara Satuan Kerja Perangkat Daerah (di singkat SKPD) dengan Satuan Kerja Pengelola Keuangan Daerah (disingkat SKPKD) sehingga data di Pemerintah Daerah dapat terintegrasi dengan baik.

Berikut ini beberapa hasil penelitan yang mengkaji mengenai pengaruh penerapan Standar Akuntansi Pemerintahan terhadap kualitas laporan keuangan. Penelitian yang dilakukan oleh Purwaniati Nugraheni dan Imam Subaweh (2008) menunjukkan terdapat pengaruh penerapan Standar Akuntansi Pemerintahan di Inspektorat Jenderal Departemen Pendidikan Nasional terhadap peningkatan kualitas laporan keuangan Inspektorat Jenderal Departemen Pendidikan Nasional. Hasil Penelitian Bambang Pamungkas (2012) menunjukkan bahwa terdapat pengaruh secara positif dan signifikan dari penerapan akuntansi sektor publik terhadap kuaitas laporan keuangan pemerintah. Nilai pengaruh penerapan akuntansi sektor publik terhadap laporan keuangan menunjukkan bahwa implementasi akuntansi dalam bentuk penerapan sistem dan teknik akuntansi, penyajian komponen laporan keuangan yang sesuai dengan tujuan laporan keuangan sangat berdampak positif dalam menghasilkan laporan keuangan yang berkualitas. Penelitian yang dilakukan oleh Daniel Kartika Adhi dan Yohanes Suhardjo (2013) menunjukkan bahwa Penerapan Standar Akuntansi Pemerintahan berpengaruh terhadap Kualitas Laporan Keuangan Pemerintah Kota Tual. Dalam Government Finance Review, kajian mengenai penerapan Standar Akuntansi Pemerintah juga dilakukan oleh Jeffrey L Esser (1992) yang menganalisis mengenai "GASB's implementation of the new measurement focus and basis on accounting " hasil pelaporannya menunjukan bahwa perubahan dalam Standar Akuntansi Pemerintahan sebagai dasar pelaporan keuangan 
akan terakses pada penurunan kredibilitas laporan keuangan pemerintah dan kemampuannya untuk dipahami oleh para pengguna, khususnya bagi entitas pelaporan yang belum sepenuhnya dapat menerapkan Standar Akuntansi Pemerintah yang baru.

Laporan keuangan pemerintah merupakan informasi yang sangat bermanfaat bagi penggunanya, untuk menghasilkan informasi yang berkualitas baik, sebuah organisasi harus mempunyai Sistem Informasi yang baik, sistem Informasi yang bertujuan menghasilkan informasi keuangan disebut dengan Sistem Informasi Akuntansi, hal ini berlaku baik untuk organisasi bisnis maupun organisasi sektor publik seperti di Pemerintah Daerah (Laudon \& Laudon, 2007). Sistem Informasi Akuntansi mengacu pada Peraturan Pemerintah No 56 tahun 2005 yang direvisi oleh Peraturan Pemerintah No 65 tahun 2010, aturan pelaksanaannya adalah Peraturan Menteri Dalam Negeri (Permendagri) No 13 tahun 2006 dan Peraturan Menteri Dalam Negeri No 59 Tahun 2007, Sistem ini berbasis pada jaringan komputer yang mampu menghubungkan dan mampu menangani konsolidasi data antara Satuan Kerja Perangkat Daerah (di singkat SKPD) dengan Satuan Kerja Pengelola Keuangan Daerah (disingkat SKPKD) sehingga data di Pemerintah Daerah dapat terintegrasi dengan baik.

Menurut Zimmerman (1997), Sistem Informasi Akuntansi memiliki peran yaitu Sistem Informasi Akuntansi berperan dalam pengendalian keputusan. Jansen dan Meckling (1992) membuktikan bahwa Sistem Informasi berhubungan dengan struktur kewenangan formal dan peran pengendalian, struktur kewenangan formal berhubungan dengan dua hal yaitu, penggunaan Sistem Informasi Akuntansi dengan tujuan untuk pengendalian perilaku bawahan (peran pengendalian) dan penggunaan Sistem Informasi Akuntansi untuk memudahkan pengambilan keputusan (peran manajemen keputusan) pada tingkat sub unit.

Implementasi Standar Akuntansi Pemerintahan dan implementasi Sistem Informasi Akuntansi di Jawa Barat diharapkan mampu menghasilkan Laporan Keuangan yang disajikan oleh Pemerintah Daerah di Kabupaten/Kota Provinsi menjadi lebih berkualitas dibandingkan dengan sebelumnya, namun dalam pelaksanaannya masih terdapat beberapa masalah menyangkut transformasi akuntansi dalam laporan keuangan. Hal ini tersebut dapat diketahui dari fenomena masalah yang teramati, yaitu : (1) Laporan Keuangan Pemerintah Daerah yang disiapkan sering mengalami keterlambatan yang berekses kepada tidak tepatnya waktu pelaporan keuangan daerah ke BPK RI. BPK RI menemukan 10 kasus Kelemahan SPI karena Entitas terlambat menyampaikan laporan. Kasus di Jawa Barat tahun 2010, laporan pertanggungJawaban keuangan Pemerintah Provinsi Jawa Barat dan 26 Kabupaten/Kota se Jawa Barat seharusnya sudah diterima oleh DPRD provinsi jabar paling lambat tanggal 30 Juni, tetapi sampai bulan juli laporan keuangan tersebut belum selesai di audit. Hal ini berimbas pada waktu pembahasan APBD tahun 2010 yang mengalami keterlambatan, akhirnya pemerintah Jawa barat memutuskan untuk melanjutkan proses penganggaran dengan meminta Gubernur menyerahkan Rancangan Peraturan Daerah pertanggungjawaban pelaksanaan APBD (irfan Suryanagara (2010). (2) Rapat konsolidasi tindak lanjut hasil pemeriksaan BPK RI yang dilaksanakan pada hari jumat tanggal 3 september 2010 oleh pimpinan pemerintahan Jawa Barat ditambah perwakilan Satuan Organisasi Perangkat Daerah (SOPD) Provinsi Jawa Barat menegaskan Rencana Implementasi Sistem Informasi Pengelolaan keuangan Daerah (SIPKD) di semua SOPD yang bertujuan agar pembuatan laporan keuangan dapat dilaksanakan dengan cepat dan akurat (H. Iwa Karniwa, 2010).(3) PerlakuanAkuntansi terhadap aset tetap adalah masalah yang paling sering di temukan dalam implementasi standar akuntansi pemerintahan terutama dalam hal pengakuan aset, penentuan nilai tercatat, serta penentuan dan perlakuan akuntansi atas penilaian kembali dan penurunan nilai tercatat (carrying value) asset tetap. Banyak aset pemerintah pusat/daerah diperoleh pada periode-periode yang telah lampau, sedangkan catatan atas harga perolehan maupun harga wajar saat perolehan tidak diketahui. Atas aset-aset tersebut tidak mungkin dinilai dengan menggunakan harga perolehan atau nilai wajar saat perolehan. aturan yang ada pada PSAP 07 tentang Akuntansi Aset Tetap Paragraf 28 adalah untuk keperluan penyusunan neraca awal suatu entitas, biaya perolehan aset tetap yang digunakan adalah nilai wajar pada saat neraca awal tersebut disusun. Nilai Wajar adalah nilai tukar aset sejenis di pasaran. Padahal, sebagaimana kita ketahui bersama, data yang ada pada Buku Inventaris pada masa itu adalah Harga Perolehan. Maka Neraca Awal pemerintah pusat tahun 2004 saat itu masih menggunakan Harga Perolehan. (4) Menurut Peraturan Pemerintah no 24 tahun 2005 tentang Standar Akuntansi Pemerintahan, 
dalam PSAP 07 tentang aset tetap disebutkan penyusutan adalah penyesuaian nilai sehubungan dengan penurunan kapasitas dan manfaat dari suatu aset. Penyusutan merupakan alat untuk mendapatkan penyajian yang wajar di neraca dari tahun ke tahun. Dalam akuntansi pemerintah, pengertian penyusutan ini berbeda dengan di swasta dimana penyusutan lebih ditujukan untuk alokasi biaya. Penyusutan telah diminta oleh PP 24/2005 dan bahkan Buletin Teknis tentang Akuntansi Penyusutan juga telah terbit. Namun hingga hari ini, di Pemerintah Pusat maupun Pemerintah Daerah masih belum terdengar kapan dilaksanakan. (5) Masalah penyajian piutang pajak dan retribusi per 31 Desember 2009 di Pemda Jabar sebesar Rp. 14,28 milyar, diantaranya merupakan piutang pajak pada Dinas Pendapatan sebesar Rp. 11,65 miliar. Nilai piutang tersebut tidak didukung dengan rincian dan dokumen sumber yang memadai. Lebih lanjut saldo tersebut berbeda sebesar Rp. 532,75 juta dibandingkan saldo menurut Unit Pelayanan Pendapatan Daerah. Hal ini dikarenakan terdapat permasalahan dalam pengendalian atas pengakuan pencatatan piutang pajak, yang berasal dari Surat Ketetapan Pajak Kurang Bayar (SKPKB) atau Surat Tagihan Pajak (STP). (6) Penyajian persediaan per 31 Desember 2009 sebesar Rp 295,17 miliar di antaranya merupakan persediaan buku pada Dinas Pendidikan sebesar Rp7,97 miliar belum disajikan berdasarkan stock opname, dan nilai persediaan alat kesehatan dan obat-obatan pada Dinas Kesehatan sebesar $\mathrm{Rp}$ 42,38 miliar belum berdasarkan stock opname secara menyeluruh. (7) Sumber Daya Manusia (SDM) yang memiliki latar belakang pendidikan akuntansi hanya sebagian kecil saja. Hasil Survey BPK menunjukan $76,77 \%$ SDM aparatur Unit Pengelola Keuangan di pemerintaha tidak berlatar belakang akuntansi (BPKP, PR online tanggal 30 april 2010). (8) Mulai dikembangkannya basis akrual di dalam standar akuntansi pemerintah dengan terbitnya PPNo 71 tahun 2010, sehingga basis cash menuju akrual merupakan langkah yang harus dipahami betul manakala akan menerapkan basis akrual sepenuhnya. (PP No 71 Tahun 2010)

Tujuan dari penelitian ini adalah untuk mengetahui dan menganalisis seberapa besar pengaruh implementasi standar akuntansi pemerintahan dan sistem informasi akuntansi secara parsial maupun simultan terhadap kualitas laporan keuangan

\section{METODE}

Penelitian ini merupakan penelitian yang bersifat deskriptif yang bertujuan mendeskripsikan atau menguraikan secara tuntas dan jelas mengenai karakteristik permasalahan atau fenomena yang di hadapi, dan penelitian yang bersifat verifikatif yaitu suatu jenis penelitian yang bertujuan untuk mengetahui hubungan antar variabel melalui suatu pengujian hipotesis. Metode yang digunakan adalah explanatory survey yaitu penelitian yang dilakukan untuk memperoleh deskripsi, gambaran atau lukisan secara sistematis, faktual dan akurat mengenai faktafakta, sifat-sifat serta hubungan antar variabel yang diteliti. Alasan peneliti memilih metode penelitian survey eksplanatori karena peneliti ingin mencari jawaban secara mendasar tentang sebab akibat dengan menganalisis faktor-faktor penyebab terjadinya suatu fenomena tertentu, yaitu fenomena yang berkaitan dengan masalah masalah dan praktek-praktek dalam penelitian ini.

Variabel dalam penelitian ini terdiri dari; (1) Implementasi Standar Akuntansi Pemerintahan $\left(\mathrm{X}_{1}\right)$, (2) Implementasi Sistem Informasi Akuntansi $\left(\mathrm{X}_{2}\right)$, Dan (3) Kualitas Laporan Keuangan (Y)

Untuk menganalisis pengaruh antara variabel implementasi standar akuntansi pemerintahan $\left(\mathrm{X}_{1}\right)$, dan implementasi Sistem Informasi Keuangan $\left(\mathrm{X}_{2}\right)$ terhadap Kualitas Laporan Keuangan (Y) digunakan teknik analisis regresi berganda (multiple regresion analysis). Alasan penggunaan analisis regresi berganda dalam penelitian ini karena variabel independen berjumlah lebih dari satu yaitu ada dua variabel.

Berdasarkan paradigma penelitian yang telah dikemukakan sebelumnya, maka model persamaan regresi berganda untuk penelitian ini dapat dirumuskan sebagai berikut:

$\mathrm{Y}=\beta_{0}+\beta_{1} \mathrm{X}_{1}+\beta_{2} \mathrm{X}_{2}+\varepsilon$

di mana:

$\mathrm{Y}=$ Kualitas Laporan Keuangan

$\beta_{0}=$ Koefisien intercept (konstanta), yaitu nilai $\mathrm{Y}$ jika nilai seluruh variabel lain adalah nol

$\beta_{1}=$ Koefisien regresi variabel $\mathrm{X}_{1}$

$\beta_{2}=$ Koefisien regresi variabel $X_{2}$

$\mathrm{X}_{1}=$ implementasi standar akuntansi pemerintahan

$\mathrm{X}_{2}=$ implementasi Sistem Informasi Keuangan

$\varepsilon=$ Error term dari variabel-variabel lain 
Hipotesis penelitian dapat dirumuskan hipotesis statistik sebagai berikut:

Hipotesis Pertama: $\mathrm{Ho}_{1}: \beta_{\mathrm{i}}=0,(\mathrm{i}=1,2)$

Implementasi Standar Akuntansi Pemerintahan $\left(X_{1}\right)$ dan Implementasi Sistem Informasi Keuangan $\left(\mathrm{X}_{2}\right)$ secara bersama-sama/simultan tidak berpengaruh positif terhadap Kualitas Laporan Keuangan Y).

Hipotesis Kedua: $\mathrm{Ho}_{2}: \beta_{\mathrm{i}} \leq 0,(\mathrm{i}=1,2)$

Implementasi Standar Akuntansi Pemerintahan $\left(X_{1}\right)$ dan Implementasi Sistem Informasi Keuangan $\left(\mathrm{X}_{2}\right)$, secara parsial tidak berpengaruh positif terhadap Kualitas Laporan Keuangan (Y).

\section{HASIL}

Sebelum dianalisis, data hasil penelitian terlebih dahulu diuji validitas dan reliabilitasnya untuk menguji apakah alat ukur yang digunakan berupa butir item pernyataan yang diajukan kepada responden telah mengukur secara cermat dan tepat apa yang ingin diukur pada penelitian ini.

\section{Uji Validitas dan Reliabilitas}

Pengujian validitas dilakukan untuk mengetahui apakah alat ukur yang dirancang dalam bentuk kuesioner benar-benar dapat menjalankan fungsinya. Seperti telah dijelaskan pada metodologi penelitian bahwa untuk menguji valid tidaknya suatu alat ukur digunakan pendekatan secara statistika, yaitu melalui nilai koefisien korelasi skor butir pernyataan dengan skor totalnya. Apabila koefisien korelasi butir pernyataan dengan skor total item lainnya $\geq 0,30$ maka pernyataan tersebut dinyatakan valid atau jika indeks validitas setiap item pertanyaan lebih besar dari indeks validitas kritisnya yaitu sebesar 0,3. Berdasarkan hasil pengolahan menggunakan korelasi product moment (indeks validitas) diperoleh hasil uji validitas yang menunjukkan semua item pertanyaan valid, karena nilai indeks validitasnya lebih besar dari nilai indeks validitas kritisnya. hasil uji ini mengindikasikan bahwa semua butir pertanyaan yang diajukan pada ketiga variabel valid dan layak digunakan sebagai alat ukur untuk penelitian dan dapat diikutsertakan pada analisis selanjutnya.

Selain valid, alat ukur juga harus memiliki keandalan atau reliabilitas, suatu alat ukur dapat diandalkan jika alat ukur tersebut digunakan berulangkali akan memberikan hasil yang relatif sama (tidak beberda jauh). Untuk melihat andal tidaknya suatu alat ukur digunakan pendekatan secara statistika, yaitu melalui koefisien reliabilitas. Apabila koefisien reliabilitas lebih besar dari 0.70 maka secara keseluruhan pernyataan dinyatakan andal (reliabel). Berdasarkan hasil pengolahan menggunakan metode alpha-cronbach diperoleh hasil uji reliabilitas seperti terlihat pada Tabel 2.

Tabel 2. Hasil Uji Reliabilitas Kuesioner Penelitian

\begin{tabular}{lccc}
\hline \multicolumn{1}{c}{ Kuesioner } & $\begin{array}{c}\text { Jumlah } \\
\text { Pertanyaan }\end{array}$ & $\begin{array}{c}\text { Koefisien } \\
\text { Reliabilitas }\end{array}$ & Keterangan \\
\hline $\begin{array}{l}\text { Standar akuntansi } \\
\text { pemerintahan }\end{array}$ & 53 & 0,985 & reliabel \\
$\begin{array}{l}\text { Sistem informasi } \\
\text { akuntansi } \\
\text { pemerintahan }\end{array}$ & 27 & 0,974 & reliabel \\
$\begin{array}{l}\text { Kualitas laporan } \\
\text { keuangan }\end{array}$ & 11 & 0,950 & reliabel \\
\hline
\end{tabular}

\section{Pengujian Asumsi Regresi}

Sebelum dilakukan pengujian hipotesis, terlebih dahulu dilakukan pengujian asumsi klasik untuk mengetahui apakah kesimpulan dari regresi tidak bias, ada beberapa asumsi yang harus terpenuhi, diantaranya adalah uji normlitas, uji multikolinieritas dan uji heteroskedastisitas.

Asumsi normalitas merupakan persyaratan yang sangat penting pada pengujian kebermaknaan (signifikansi) koefisien regresi, apabila model regresi tidak berdistribusi normal maka kesimpulan dari uji $\mathrm{F}$ dan uji $\mathrm{t}$ masih meragukan, karena statistik uji $\mathrm{F}$ dan uji t pada analisis regresi diturunkan dari distribusi normal. Pada penelitian ini digunakan uji satu sampel Kolmogorov-Smirnov untuk menguji normalitas model regresi.

Pada Tabel 3. dapat dilihat nilai probabilitas (signifikansi) yang diperoleh dari uji KolmogorovSmirnov sebesar 0,765. Karena nilai probabilitas pada uji Kolmogorov-Smirnov masih lebih besar dari tingkat kekeliruan 5\% (0.05), maka disimpulkan bahwa model regresi berdistribusi normal.

Multikolinieritas berarti adanya hubungan yang kuat di antara beberapa atau semua variabel independen pada model regresi. Jika terdapat Multikolinieritas maka koefisien regresi menjadi tidak tentu, tingkat kesalahannya menjadi sangat besar dan biasanya ditandai dengan nilai koefisien determinasi yang sangat besar tetapi pada pengujian parsial, tidak 
ada ataupun kalau ada sangat sedikit sekali koefisien regresi yang signifikan. Pada penelitian ini digunakan nilai variance inflation factors (VIF) sebagai indikator ada tidaknya multikolinieritas diantara variabel independen.

Tabel 3. Hasil Pengujian Asumsi Normalitas

One-Sample Kolmogorov-Smirnov Test

\begin{tabular}{|c|c|c|}
\hline \multicolumn{3}{|c|}{$\begin{array}{c}\text { Unstandardized } \\
\text { Residual }\end{array}$} \\
\hline $\mathrm{N}$ & & 26 \\
\hline \multirow[t]{2}{*}{ Normal Parameters ${ }^{\mathrm{a}, \mathrm{b}}$} & Mean & .0000000 \\
\hline & Std. Deviation & .83182800 \\
\hline Most Extreme & Absolute & .131 \\
\hline \multirow[t]{2}{*}{ Differences } & Positive & .127 \\
\hline & Negative & -.131 \\
\hline Kolmogorov-Smirnov $Z$ & & 667 \\
\hline Asymp. Sig. (2-tailed) & & .765 \\
\hline \multicolumn{3}{|c|}{$\begin{array}{l}\text { a. Test distribution is Normal } \\
\text { b. Calculated from data }\end{array}$} \\
\hline \multicolumn{3}{|c|}{$\begin{array}{l}\text { Berdasarkan nilai VIF yang diperoleh seperti } \\
\text { pada Tabel 4. menunjukkan tidak ada korelasi } \\
\text { yang kuat antara sesama variabel independen, hal } \\
\text { ini ditunjukkan oleh nilai VIF dari kedua variabel } \\
\text { independen masih lebih kecil dari } 10 \text { dan dapat } \\
\text { disimpulkan tidak terdapat multikolinieritas diantara } \\
\text { kedua variabel independen. }\end{array}$} \\
\hline \multicolumn{3}{|c|}{ Tabel 4. Hasil Pengujian Asumsi Multikolinieritas } \\
\hline \multicolumn{3}{|c|}{ Coefficients $^{a}$} \\
\hline & \multicolumn{2}{|c|}{ Collinearity Statistics } \\
\hline Model & Tolerance & VIF \\
\hline \multirow[t]{3}{*}{1} & & \\
\hline & .971 & 1.029 \\
\hline & .971 & 1.029 \\
\hline
\end{tabular}

a. Dependent Variable: KLK

Heteroskedastisitas merupakan indikasi varian antar residual tidak homogen yang mengakibatkan nilai taksiran yang diperoleh tidak lagi efisien. Untuk menguji apakah varian dari residual homogen digunakan uji rank Spearman, yaitu dengan mengkorelasikan variabel independen terhadap nilai absolut residual (error). Apabila ada koefisien korelasi variabel independen yang signifikan, mengindikasikan adanya heteroskedastisitas. Pada
Tabel 5. berikut dapat dilihat nilai signifikansi masingmasing korelasi variabel independen terhadap nilai absolut dari residual(error).

Berdasarkan hasil korelasi yang diperoleh seperti dapat dilihat pada Tabel 5. memberikan suatu indikasi bahwa residual (error) yang muncul dari persamaan regresi mempunyai varians yang sama (tidak terjadi heteroskedastisitas), dimana nilai signifikansi dari masing-masing koefisien regresi kedua variabel independen dengan nilai absolut error masih lebih besar dari 0,05 (yaitu 0,188 dan 0,100).

Tabel 5. Hasil Pengujian Asumsi Heteroskedastisitas

\begin{tabular}{|c|c|c|}
\hline \multicolumn{3}{|c|}{ Corelation } \\
\hline & & absolut_error \\
\hline \multirow[t]{6}{*}{ Spearman's rho } & Correlation Coefficient & -.266 \\
\hline & Sig. (2-tailed) & .188 \\
\hline & $\mathrm{N}$ & 26 \\
\hline & Correlation Coefficient & -.330 \\
\hline & Sig. (2-tailed) & .100 \\
\hline & $\mathrm{N}$ & 26 \\
\hline
\end{tabular}

Karena ketiga asumsi regresi terpenuhi, maka dapat disimpulkan bahwa hasil estimasi model regresi standar akuntansi pemerintahan dan sistem informasi akuntansi pemerintahan terhadap kualitas laporan keuangan memenuhi syarat BLUE (best linear unbias estimation) sehingga kesimpulan yang diperoleh dari model regresi sudah mewakili keadaan yang sebenarnya.

\section{Analisis Korelasi}

Analisis korelasi bertujuan untuk mengetahuai kekuatan hubungan kedua variabel independen (pengaruh standar akuntansi pemerintahan dan sistem informasi akuntansi pemerintahan) dengan kualitas laporan keuangan. Berdasarkan hasil pengolahan data diperoleh koefisien korelasi dari kedua variabel independen dengan kualitas laporan keuangan (Tabel 6.).

Berdasarkan nilai koefisien korelasi pada Tabel 6. dapat diketahui bahwa variabel standar akuntansi pemerintahan (SAP) memiliki hubungan yang kuat/erat dengan kualitas laporan keuangan pada pemerintah kabupaten/kota di Propinsi Jawa Barat. Kemudian variabel sistem informasi akuntansi pemerintahan (SIA) memiliki hubungan yang cukup kuat/cukup erat dengan kualitas laporan keuangan 
pada pemerintah kabupaten/kota di Propinsi Jawa Barat.

Tabel 5. Hasil Pengujian Asumsi Heteroskedastisitas

\begin{tabular}{lrrrr}
\multicolumn{5}{c}{ Corelation } \\
\hline Pearson & KLK & \multicolumn{1}{c}{ SAP } & \multicolumn{1}{c}{ SIA } \\
Correlation & KLK & 1.000 & .641 & .518 \\
& SAP & .641 & 1.000 & .169 \\
& SIAP & .518 & .169 & \\
Sig. (1-tailed) & KLK &. & .000 & .003 \\
& SAP & .000 & & .205 \\
& SIA & .003 & .205 & \\
& KLK & 26 & & 26 \\
& SAP & 26 & & 26 \\
& SIA & 26 & & 26 \\
\hline
\end{tabular}

\section{Estimasi Model Regresi}

Analisis regresi digunakan untuk menguji perubahan yang terjadi pada kualitas laporan keuangan yang dapat diterangkan atau dijelaskan oleh perubahan kedua variabel independen (standar akuntansi pemerintahan dan sistem informasi akuntansi pemerintahan). Berdasarkan hasil pengolahan data standar akuntansi pemerintahan dan sistem informasi akuntansi pemerintahan terhadap kualitas laporan keuangan dapat dilihat pada Tabel 7.

Tabel 7. Hasil Regresi Standar Akuntansi Pemerintahan (SAP) dan Sistem Informasi Akuntansi Pemerintahan

(SIA) terhadap Kualitas laporan keuangan (KLK)

\begin{tabular}{|c|c|c|c|c|c|}
\hline \multicolumn{6}{|c|}{ Coefficients $^{a}$} \\
\hline \multirow[b]{2}{*}{ Model } & \multicolumn{2}{|c|}{$\begin{array}{l}\text { Unstandardized } \\
\text { Coefficients }\end{array}$} & \multirow{2}{*}{$\begin{array}{c}\begin{array}{c}\text { Standardized } \\
\text { Coefficients }\end{array} \\
\text { Beta }\end{array}$} & \multirow[b]{2}{*}{$\mathrm{t}$} & \multirow[b]{2}{*}{ Sig. } \\
\hline & B & Std. Error & & & \\
\hline 1 (Constant) & -1.848 & 1.520 & & -.976 & .399 \\
\hline SAP & .730 & .175 & .570 & 4.176 & .000 \\
\hline SIA & .472 & .153 & .422 & 3.095 & .005 \\
\hline
\end{tabular}

a. Dependent Variable: KLK

Berdasarkan hasil pengolahan data seperti diuraikan pada Tabel 7. maka dapat dibentuk persamaan regresi variabel standar akuntansi pemerintahan dan sistem informasi akuntansi pemerintahan terhadap kualitas laporan keuangan sebagai berikut.

$\mathrm{KLK}=-1,484+0,730 \mathrm{SAP}+0,472$ SIA
Pada persamaan regresi tersebut, dapat dilihat koefisien regresi dari kedua variabel independen bertanda positif yang menunjukkan bahwa pelaksanaan standar akuntansi pemerintahan dan sistem informasi akuntansi pemerintahan yang baik akan meningkatkan kualitas laporan keuangan pada pemerintah kabupaten/kota di Propinsi Jawa Barat. Selanjutnya untuk menguji apakah pengaruh standar akuntansi pemerintahan dan sistem informasi akuntansi pemerintahan terhadap kualitas laporan keuangan signifikan secara statistik, baik secara bersama-sama (simultan) maupun secara parsial (individual), dilakukan uji signifikansi. Pengujian dimulai dari pengujian simultan, dan apabila hasil pengujian simultan signifikan dilanjutkan dengan uji parsial.

\section{Pengujian Koefisien Regresi Secara Simultan}

Pengujian secara simultan bertujuan untuk membuktikan apakah standar akuntansi pemerintahan dan sistem informasi akuntansi pemerintahan secara simultan berpengaruh signifikan terhadap kualitas laporan keuangan pada pemerintah kabupaten/kota di Propinsi Jawa Barat dengan rumusan hipotesis statistik sebagai berikut.

Ho: Semua $\beta i=0$ Standar akuntansi pemerintahan $\mathrm{i}=1,2$ dan sistem informasi akuntansi pemerintahan secara simultan tidak berpengaruh terhadap kualitas laporan keuangan pada pemerintah kabupaten/kota di Propinsi Jawa Barat.

Ha: Ada $\beta i \neq 0 \quad$ Standar akuntansi pemerintahan $i=1,2 \quad$ dan sistem informasi akuntansi pemerintahan secara simultan berpengaruh terhadap kualitas laporan keuangan pada pemerintah kabupaten/kota di Propinsi Jawa Barat.

Untuk menguji hipotesis tersebut digunakan statistik uji-F yang diperoleh melalui tabel anova seperti yang tercantum pada Tabel 8 .

Berdasarkan Tabel 8. dapat dilihat nilai $\mathrm{F}_{\text {hitung }}$ dari hasil pengolahan data sebesar 16,155 dan nilai ini menjadi statistik uji yang akan dibandingkan dengan nilai F dari tabel. Dari tabel F pada $\alpha=0.05$ dan derajat bebas $(2 ; 23)$ diperoleh nilai $\mathrm{F}_{\text {tabel }}$ sebesar 3,422 . Karena $\mathrm{F}_{\text {hitung }}(16,155)$ lebih besar dari $\mathrm{F}_{\text {tabel }}$ 
$(3,422)$ maka pada tingkat kekeliruan 5\% $(\alpha=0.05)$ diputuskan untuk menolak Ho dan menerima Ha. Artinya dengan tingkat kepercayaan 95\% dapat disimpulkan bahwa standar akuntansi pemerintahan dan sistem informasi akuntansi pemerintahana secara simultan (bersama-sama) berpengaruh signifikan terhadap kualitas laporan keuangan pada pemerintah kabupaten/kota di Propinsi Jawa Barat.

Tabel 8. Pengujian Koefisien Regresi Secara Bersama-sama

\section{ANOVA}

\begin{tabular}{llrrrrr}
\hline & & $\begin{array}{c}\text { Sum of } \\
\text { Squares }\end{array}$ & df & $\begin{array}{c}\text { Mean } \\
\text { Square }\end{array}$ & F & Sig. \\
\hline 1 Regression & 24.300 & 2 & 12.150 & 16.155 & $.000^{\text {a }}$ \\
Residual & 17.298 & 23 & .752 & & \\
Total & 41.599 & 23 & & & \\
\hline
\end{tabular}

a. Predictors: (Constant), SIA, SAP

b. Dependent Variable: KLK

\section{Pengujian Koefisien Regresi Secara Parsial}

Pada pengujian koefisien regresi secara parsial akan diuji pengaruh masing-masing variabel independen terhadap variabel dependen. Statistik uji yang digunakan pada pengujian parsial adalah uji t. Nilai tabel yang digunakan sebagai nilai kritis pada uji parsial (uji t) sebesar 2,069 yang diperoleh dari tabel t pada $\alpha=0.05$ dan derajat bebas 23 untuk pengujian dua pihak.

Dugaan sementara bahwa standar akuntansi pemerintahan berpengaruh terhadap kualitas laporan keuangan pada pemerintah kabupaten/kota di Propinsi Jawa Barat, karena dugaan tersebut peneliti menetapkan hipotesis penelitian untuk pengujian dua pihak dengan rumusan hipotesis sebagai berikut.

Ho. $\beta_{1}=0$ Standar akuntansi pemerintahan tidak berpengaruh terhadap kualitas laporan keuangan pada pemerintah kabupaten/kota di Propinsi Jawa Barat.

Ha. $\beta_{1} \neq 0$ Standar akuntansi pemerintahan tidak berpengaruh terhadap kualitas laporan keuangan pada pemerintah kabupaten/kota di Propinsi Jawa Barat.

Berdasarkan data seperti disajikan pada Tabel 7. diperoleh nilai $t_{\text {hitung }}$ variabel standar akuntansi pemerintahan sebesar 4,176 . Karena nilai $t_{\text {hitung }}$ $(4,176)$ lebih besar dari $t_{\text {tabel }}(2,069)$ maka pada tingkat kekeliruan 5\% diputuskan untuk menolak Ho dan menerima Ha, artinya dengan tingkat kepercayaan 95\% dapat disimpulkan bahwa standar akuntansi pemerintahan berpengaruhsignifikan terhadapkualitas laporan keuangan. Hasil pengujian ini memberikan bukti empiris bahwa pelaksanaan standar akuntansi pemerintahan yang baik akan meningkatkan kualitas laporan keuangan pada pemerintah kabupaten/kota di Propinsi Jawa Barat.

Dugaan sementara sistem informasi akuntansi pemerintahan berpengaruh terhadap kualitas laporan keuangan pada pemerintah kabupaten/kota di Propinsi Jawa Barat, karena dugaan tersebut peneliti menetapkan hipotesis penelitian untuk pengujian dua pihak dengan rumusan hipotesis sebagai berikut.

Ho. $\beta_{2}=0$ Sistem informasi akuntansi pemerintahan tidak berpengaruh terhadap kualitas laporan keuangan pada pemerintah kabupaten/kota di Propinsi Jawa Barat.

Ha. $\beta_{2} \neq 0$ Sistem informasi akuntansi pemerintahan tidak berpengaruh terhadap kualitas laporan keuangan pada pemerintah kabupaten/kota di Propinsi Jawa Barat.

Berdasarkan data seperti disajikan pada Tabel 7. diperoleh nilai $t_{\text {hitung }}$ variabel sistem informasi akuntansi pemerintahana sebesar 3,095. Karena nilai $\mathrm{t}_{\text {hitung }}(3,095)$ lebih besar dari $\mathrm{t}_{\text {tabel }}(2,069)$ maka pada tingkat kekeliruan 5\% diputuskan untuk menolak Ho dan menerima $\mathrm{Ha}$, artinya dengan tingkat kepercayaan $95 \%$ dapat disimpulkan bahwa sistem informasi akuntansi pemerintahan berpengaruh signifikan terhadap kualitas laporan keuangan. Hasil pengujian ini memberikan bukti empiris bahwa sistem informasi akuntansi pemerintahan yang baik akan meningkatkan kualitas laporan keuangan pada pemerintah kabupaten/kota di Propinsi Jawa Barat.

\section{Koefisien Determinasi}

Koefisien determinasi merupakan suatu nilai yang menyatakan besar pengaruh secara simultan semua variabel independen terhadap variabel dependen. Pada permasalahan yang diteliti yaitu pengaruh simultan variabel standar akuntansi pemerintahan dan sistem informasi akuntansi pemerintahan terhadap kualitas laporan keuangan diperoleh koefisien determinasi seperti yang disajikan pada Tabel 9 .

Nilai R pada Tabel 9. menunjukkan kekuatan hubungan kedua variabel independen (standar akuntansi pemerintahan dan sistem informasi 
akuntansi pemerintahan) secara simultan dengan kualitas laporan keuangan. Jadi pada pemerintah kabupaten/kota di Propinsi Jawa Barat diketahui bahwa secara simultan kedua variabel independen (standar akuntansi pemerintahan dan sistem informasi akuntansi pemerintahan) memiliki hubungan yang kuat dengan kualitas laporan keuangan.

Tabel 9. Koefisien Determinasi

\begin{tabular}{rrrrr}
\multicolumn{5}{c}{ Model Sumarry $^{\mathbf{b}}$} \\
\hline Model & R & R Square & $\begin{array}{l}\text { Adjusted } \\
\text { R Square }\end{array}$ & $\begin{array}{c}\text { Std. Error } \\
\text { of the Estimate }\end{array}$ \\
\hline 1 & $.764^{\text {a }}$ & .584 & .548 & .86724
\end{tabular}

a. Predictors: (Constant), SIA, SAP

b. Dependent Variable: KLK

Sementara nilai $R$-Square sebesar 0,584 atau 58,4 persen menunjukkan bahwa pada pemerintah kabupaten/kota di Propinsi Jawa Barat, variabel standar akuntansi pemerintahan dan sistem informasi akuntansi pemerintahan secara simultan mampu menerangkan perubahan yang terjadi pada kualitas laporan keuangan sebesar 58,4 persen. Dengan kata lain standar akuntansi pemerintahan dan sistem informasi akuntansi pemerintahan secara bersamasama memberikan kontribusi atau pengaruh sebesar $58,4 \%$ terhadap perubahan kualitas laporan keuangan. Sisanya pengaruh faktor-faktor lain yang tidak diamati adalah sebesar $41,6 \%$, yaitu merupakan pengaruh faktor lain diluar variabel standar akuntansi pemerintahan dan sistem informasi akuntansi pemerintahan.

Besar pengaruh masing-masing variabel independen terhadap kualitas laporan keuangan dapat dihitung dengan mengalikan nilai standardized coefficients yang terdapat pada Tabel 7. dengan nilai korelasi yang terdapat pada Tabel 6., maka besar pengaruh standar akuntansi pemerintahan terhadap kualitas laporan keuangan $=0,570 \times 0,641=0,365$ atau 36,5 persen. Besarnya pengaruh sistem informasi akuntansi pemerintahan terhadap kualitas laporan keuangan $=0,422 \times 0,518=0,219$ atau 21,9 persen.

Berdasarkan hasil perhitungan besar pengaruh/ kontribusi masing-masing variabel independen terhadap kualitas laporan keuangan dapat diketahui bahwa diantara kedua variabel independen, standar akuntansi pemerintahan memberikan pengaruh yang lebih besar terhadap kualitas laporan keuangan pada pemerintah kabupaten/kota di Propinsi Jawa Barat.

\section{PEMBAHASAN}

\section{Pengaruh Implementasi Standar Akuntansi Pemerintahan terhadap Kualitas Laporan Keuangan}

Hipotesis yang menyatakan bahwa standar akuntansipemerintahan berpengaruh terhadap kualitas laporan keuangan telah terbukti melalui pengujian. Melalui uji-t dengan tingkat kekeliruan 5\% $(\alpha=0.05)$, diperoleh hasil bahwa hipotesis yang menyatakan standar akuntansi pemerintahan tidak berpengaruh terhadap kualitas laporan keuangan $\left(\mathrm{H}_{0}\right)$ ditolak. Dengan kata lain dapat disimpulkan bahwa terdapat pengaruh yang signifikan dari standar akuntansi pemerintahan terhadap kualitas laporan keuangan. Besarnya kontribusi atau pengaruh standar akuntansi pemerintahan secara parsial terhadap kualitas laporan keuangan adalah $36,5 \%$, artinya $36,5 \%$ peningkatan kualitas laporan keuangan dapat dijelaskan oleh pelaksanaan standar akuntansi pemerintahan. Dari distribusi penilaian responden terhadap implementasi standar akuntansi pemerintahan dapat dilihat bahwa penilaianrespondendentertinggiterdapatpadadimensi pengakuan dan dimensi pengungkapan, pengakuan di wujudkan dalam penggunaan basis akuntansi yang digunakan dalam laporan keuangan sementara pengungkapan diwujudkan dalam penyajian secara lengkap atas seluruh informasi yang dibutuhkan para pengguna. sementara untuk penilaian responden terhadap kualitas laporan keuangan tertinggi terdapat pada dimensi relevan, relevan artinya informasi harus memiliki kaitan dengan keputusan yang akan di ambil. Dari hasil penilaian responden dapat di simpulkan bahwa laporan keuangan relevan karena penggunaan basis akuntansi yang sangat sesuai dengan standar akuntansi pemerintahan dan penyajian yang lengkap atas seluruh informasi.

Hasil penelitian ini memberikan bukti empiris bahwa implementasi standar akuntansi pemerintahan yang baik akan meningkatkan kualitas laporan keuangan pada pemerintah kabupaten/kota di Propinsi Jawa Barat sebagai mana Peraturan Pemerintah Nomor 24 tahun 2005 mengenai Standar Akuntansi Pemerintahan (SAP). 


\section{Pengaruh Implementasi Sistem Informasi Akuntansi Pemerintahan terhadap Kualitas Laporan Keuangan}

Hipotesis yang menyatakan bahwa sistem informasi akuntansi pemerintahan berpengaruh terhadap kualitas laporan keuangan telah terbukti melalui pengujian. Melalui uji-t dengan tingkat kekeliruan 5\% $(\alpha=0.05)$, diperoleh hasil bahwa hipotesis yang menyatakan sistem informasi akuntansi pemerintahan tidak berpengaruh terhadap kualitas laporan keuangan $\left(\mathrm{H}_{0}\right)$ ditolak. Dengan kata lain dapat disimpulkan bahwa terdapat pengaruh yang signifikan dari sistem informasi akuntansi pemerintahan terhadap kualitas laporan keuangan. Besarnya kontribusi atau pengaruh sistem informasi akuntansi pemerintahan secara parsial terhadap kualitas laporan keuangan adalah $21,9 \%$, artinya $21,9 \%$ peningkatan kualitas laporan keuangan dapat dijelaskan oleh sistem informasi akuntansi pemerintahan. Hasil penilaian responden terhadap implementasi sistem informasi akuntansi tertinggi pada dimensi software dan terdokumentasinya prosedur, dapat di jelaskan bahwa software yang baik memiliki pengendalian yang baik, software yang baik menunjukan pengolahan data yang baik pula sehingga kemungkinan kesalahan pengolahan data sangat minim, dengan demikian software yang baik akan menghasilkan output berupa laporan keuangan yang baik pula, demikian juga dengan terdokumentasinya prosedur yang baik akan merekam seluruh transaksi dan prosedur dengan tepat, sehingga laporan keuangan yang disajikan berisi informasi yang sangat lengkap dan laporan keuangan yang dihasilkan dapat dimanfaatkan dengan baik oleh para pengambil keputusan. Hasil penelitian ini juga memberikan bukti empiris bahwa sistem informasi akuntansi pemerintahan yang baik akan meningkatkan kualitas laporan keuangan pada pemerintah kabupaten/ kota di Propinsi Jawa Barat. Sejalan dengan apa yang diutarakan oleh Romney \& Steinbar (2009) bahwa Sistem informasi Akuntansi memiliki kontribusi yang kuat terhadap Kualitas Laporan Keuangan, terutama dalam proses penyusunan dan penyajian laporan keuangan yang dihasilkan.Hasil penelitian ini sejalan dengan penelitian Safrida Yuliani, Nadirsah, dan Usman Bakar (2010) bahwa pemanfaatan sistem informasi akuntansi keuangan daerah berpengaruh terhadap kualitas lapran keuangan.

\section{Pengaruh Implementasi Standar Akuntansi Pemerintahan dan Sistem Informasi Akuntansi Pemerintahan Secara Simultan terhadap Kualitas Laporan Keuangan}

Hipotesis yang menyatakan bahwa standar akuntansi pemerintahan dan sistem informasi akuntansi pemerintahan secara simultan berpengaruh terhadap kualitas laporan keuangan telah terbukti melalui pengujian. Melalui uji-F pada tingkat kekeliruan 5\% $(\alpha=0.05)$ diperoleh hasil bahwa hipotesis yang menyatakan standar akuntansi pemerintahan dan sistem informasi akuntansi pemerintahan secara simultan tidak berpengaruh terhadap kualitas laporan keuangan $\left(\mathrm{H}_{0}\right)$ ditolak. Dengan kata lain dapat disimpulkan bahwa terdapat pengaruh standar akuntansi pemerintahan dan sistem informasi akuntansi pemerintahan secara simultan terhadap kualitas laporan keuangan. Besarnya pengaruh standar akuntansi pemerintahan dan sistem informasi akuntansi pemerintahan secara simultan secara simultan terhadap kualitas laporan keuangan adalah $58,4 \%$, artinya $58,4 \%$ peningkatan kualitas laporan keuangan dapat dijelaskan oleh implementasi standar akuntansi pemerintahan dan implementasi sistem informasi akuntansi pemerintahan secara simultan.

Hal ini dapat di simpulkan bahwa kualitas laporan keuangan dinilai cukup bagus dikarenakan implementasi standar akuntansi pemerintahan dan implementasi sistem informasi akuntansi yang digunakan juga cukup bagus. Implementasi standar akuntansi pemerintahan yang dilakukan oleh pemda di Jawa Barat menunjukkan bahwa dari segi pengakuan, pengukuran, penyajian dan pengungkapan standar akuntansi pemerintahan sebagian besar telah di dilakukan dengan baik dalam proses penyusunan laporan keuangan, sehingga kualitas laporan keuangan yang dihasilkan dapat merepresentasikan kondisi keuangan pemerintahan dengan cukup baik. Implementasi sistem informasi akuntansi yang dilakukan di kota/kabupaten di wilayah Jawa Barat menunjukan bahwa komponen-komponen dalam sistem informasi akuntansi yang digunakan sebagian besar telah menunjukan kualitas yang sesuai dengan kualifikasi yang dibutuhkan, sangat membantu dan sangat memadai sehingga dapat mendukung dengan cukup baik laporan keuangan yang disajikan . Hasil 
penelitian ini memberikan bukti empiris bahwa standar akuntansi pemerintahan yang baik dan sistem informasi akuntansi pemerintahan yang baik akan meningkatkan kualitas laporan keuangan pada pemerintah kabupaten/kota di Propinsi Jawa Barat. Hal ini menunjukan bahwa penciptaan akuntabilitas publik harus dilaksanakan dalam sistem dan standar akuntansi pemerintahan untuk dapat menciptakan Good Governance, sesuai dengan PP no 24 tahun 2005.

Besarnya pengaruh standar akuntansi pemerintahan dan sistem informasi akuntansi pemerintahan secara simultan terhadap kualitas laporan keuangan adalah $58,4 \%$, sementara sisanya sebesar 42,6\% disebabkan oleh faktor-faktor lain yang tidak diteliti. faktor faktor lain tersebut merupakan faktor yang memberikan pengaruh terhadap kualitas laporan keuangan yang juga dapat meningkatkan kualitas laporan keuangan.

\section{KESIMPULAN}

Berdasarkan hasil penelitian yang telah diuraikan dapat bahwa implementasi standar akuntansi pemerintahan berpengaruh secara positif dan signifikan terhadap kualitas laporan keuangan. Hasil penelitian ini memberikan bukti empiris bahwa implementasi standar akuntansi pemerintahan yang baik akan meningkatkan kualitas laporan keuangan pada pemerintah kabupaten/kota di Propinsi Jawa Barat sebagai mana Peraturan Pemerintah Nomor 24 tahun 2005 mengenai StandarAkuntansi Pemerintahan (SAP).

Implementasi sistem informasi akuntansi berpengaruh secara positif dan signifikan terhadap kualitas laporan keuangan. Hasil penelitian ini juga memberikan bukti empiris bahwa sistem informasi akuntansi pemerintahan yang baik akan meningkatkan kualitas laporan keuangan pada pemerintah kabupaten/kota di Propinsi Jawa Barat. Sejalan dengan apa yang diutarakan oleh Romney \& steinbar dan Sri Mulyani bahwa Sistem informasi Akuntansi memiliki kontribusi yang kuat terhadap Kualitas Laporan Keuangan, terutama dalam proses penyusunan dan penyajian laporan keuangan yang dihasilkan.

Penelitian ini juga menyimpulkan bahwa penerapan standar akuntansi pemerintahan dan penerapan sistem informasi akuntansi berpengaruh secara simultan terhadap kualitas laporan keuangan.
Hasil penelitian ini memberikan bukti empiris bahwa standar akuntansi pemerintahan yang baik dan sistem informasi akuntansi pemerintahan yang baik akan meningkatkan kualitas laporan keuangan pada pemerintah kabupaten/kota di Propinsi Jawa Barat. Hal ini menunjukan bahwa penciptaan akuntabilitas publik harus dilaksanakan dalam sistem dan standar akuntansi pemerintahan untuk dapat menciptakan Good Governance, sesuai dengan PP no 24 tahun 2005.

\section{DAFTAR PUSTAKA}

Boyne, G and J. Law. 1991. Accountability and local authority Annual Reports: The Case of Weels District Councils. Financial Accountability \& Management, 7: 179-194.

Chang and Mos. 1985. An Empirical Study on the Impact of Culture on Audit Detected Accounting Errors Auditing: A Journal of Practise and Theory, 22: (Sept) 2003.

Coy et al. 2002. Public Accounting: A New Paradigm for Collage and University Annual Report; Critical Perspectives on Accounting, 12: 1-31.

Hooks et al. 2002. The Information Gap in Annual Report Accounting. Auditing and Accountability Journal, 15(4): 93-109.

Ikhtisar Hasil Pemeriksan BPK Semester II Tahun 2010 . Melalui http://www.bpk go.id [13/03/2011]

Irfan Suryanagara. 2010. Laporan IHPS II BPKP. Melalui(http://www.Tempo.co) [13/03/2011] Iwa Kartiwa. 2010. Melalui http://www. bakesbangpolinmasda.jabar.prov.go.id [25/09/2011]

Jansen Mc, Meckling WH. 1992. Specific and General Knowledge and Organizational Structure, In: Werin. L. Wijkander. H, editor, Main Currents in Contract Economics, Massachussets; Blackwell publisher, 251-91.

Jeffrey Lesser. 1992. Multi Agent Planning as a Social Process; Voting, Privacy, and Manupalition. In Victor R lesser, editor, Proceedings of the First Intermediate Conferences on Multi-Agent Systems (ICMAS-95) 431, San Francisco, SA, 1995.

Kartika Adhi, Daniel, Yohanes Suhardjo. 2013. Pengaruh Penerapan Standar Akuntansi Pemerintahan dan Kualitas Aparatur Pemerintah Daerah terhadap Kualitas Laporan Keuangan (studi kasus pada Pemerintah Kota Tual). Jurnal STIE Semarang, 3(3). 
Komite Standar Akuntansi Pemerintahan, Peraturan Pemerintah Nomor 24 Tahun 2005 tentang Standar Akuntansi Pemerintahan, Jakarta: Salemba Empat.

Marshall B, Romney, Paul John Steinbart. 2006. Accounting Information System ( $9^{\text {th }}$ edition), Prentice Hall.

Marston and Shrives. 1991. The Use of Disclosure Indices in Accounting Research: A Review Article; British Accounting Review, 23: 195-210.

Nugrahaeni, Purwaniati \& Imam Subaweh. 2008. Pengaruh Penerapan Standar Akuntansi Pemerintah terhadap Kualitas Laporan Keuangan. Jurnal Ekonomi dan Bisnis, 13(1).

Pamungkas, Bambang. 2012. Pengaruh penerapan akuntansi sektor publik dan pengawasan terhadap kualitas laporan keuangan dan implikasinya terhadap akuntabilitas kinerja instansi pemerintah. Jurnal Ilmiah Ranggagading, 12(2): 82-93.

Parker L and J Guthrei: New Accountability Regimes in Motion, Journal of International Accounting Auditing \& Taxation, 21(1): 59-81.
Slamet Kurniawan. 2010. <http://www.BPKP.go.id $>$ Standbury, M,Reilley,M. J. \& Rosenmen Kd. 2003. Work-Related Amputation Michigan, 1997. American Journal of Industrial Medicine, 44(4): 359-367.

Winfield, R. 1978, Share holder opinion of published financial statement, in Courtis.j (ed), Corporate annual Report Analysis, afm explorating series no.5, university of New England,PP.176-14

Yuliani, Safrida, Nadirsyah, Usman Bakar. 2013. Pengaruh pemahaman akuntansi, pemanfaatan sistem informasi keuangan daerah dan peran internal audit terhadap kualitas laporan keuangan Pemerintah Daerah (Studi Pada Pemerintah Kota Banda Aceh). Jurnal Telaah dan Riset Akuntansi. 3(2): 206-220.

Zimmerman. 1997, Economic value added and divisional performance measurement: capturing synergies and other issues, Journal applied corporate finance. 98-109. 